\title{
Farsça-Türkçe ve Osmanlı Türkçesi Sözlüklerinde Karșlașilan Çeviri Yazı ve İmla Meseleleri Üzerine Bazı Tespit ve Değerlendirmeler ${ }^{*}$
}

\section{Adem UZUN*}

\section{ÖZ}

Batılıların Doğuya olan ilgi ve alakalarıyla ortaya çıkan çeviri yazı, Latin alfabesinin 3 Kasım 1928'de kabulüyle birlikte gündemimize giren önemli konulardan biridir. Asırlarca kullanılan bir alfabenin başka bir yazı sistemi ile kullanılması elbette bazı sorunları da beraberinde getirecektir. Çeviri yazı da bu sorunlardan biridir. Batılılar, bu konuyu XVII. yüzyılda Meninski tarafından telif edilip Arapça, Farsça ve Türkçe sözcüklerin Latince karşılıklarını içeren Thesaurus Linguarum Orientalium adlı lügatle başlatır ve Londra'da kurulan The Royal Asiatic Society'nin Sanskrit ve Arap alfabesi için bir komisyona hazırlattığ1 transkripsiyon sisteminin 1894'te yayımlanmasıyla belli bir ölçüde sonuçlandirır.

Osmanlılarda özellikle Tanzimat dönemiyle birlikte alfabenin yetersizlikleri ve eksiklikleri olduğu konuşulmuş ve buradan hareketle değiştirilmesi ya da ıslah edilmesi gündeme gelmiştir. Bu konuda bilim adamları tarafından araştırma ve çalışmalar yapılmıştır. Türkiye Cumhuriyeti'nde Arap ve Latin alfabesi meselesini gündeme taşıyan ilk eserlerden biri, 1925 yılında Avram Galanti tarafindan yazılan Türkçede Arabî ve Latin Harfleri ve Imlâ Meseleleri adlı eserdir. Tanzimat'la birlikte konuşulmaya başlayan Latin alfabeye geçiş konusu Cumhuriyetin kurulmasıyla hızlanmı̧ ve 1928'de Latin alfabesinin kabulüyle noktalanmıştır.

* Bu makale, 19-20 Aralık 2017 tarihinde İstanbul'da Türk Dil Kurumu ile İstanbul Üniversitesi Edebiyat Fakültesinin iş birliğiyle düzenlenen “Türkçenin Yazım Sorunları Sempozyumu”nda sunulan bildiriden genişletilerek hazırlanmıştır.

** Dr., Atatürk Kültür Merkezi Başkanlığı, Çankaya - Ankara/ Türkiye

E-posta: ademuzunsmc@gmail.com, ORCID: 0000-0002-5029-3003,DOI: 10.32704/erdem.749167 Makale Gönderim Tarihi: 01.10.2019* Makale Kabul Tarihi: 17.01.2020 * (Araştırma Mk.) 
Batıda yapılan çalı̧malardan hareketle çeviri yazının Türkçe ses uyumuna uygun yazım simgeleri/harfleri, ister transkripsiyon ister transliterasyon açısından olsun belirlenmiştir. Bu itibarla Türkiye'de Osmanlı Türkçesi ile yapılan akademik çalışmalarda, günümüz Türkçesine aktarma işlemi, biri Millî Eğitim Bakanlığı İslâm Ansiklopedisi, diğeri Türkiye Diyanet Vakfi İslâm Ansiklopedisi olmak üzere iki temel eser dikkate alınarak uygulanmıştır. Bunun yanı sıra bazı kamu kurumları, örgütler ve üniversiteler bu iki eserden hareketle kendi yazım kurallarını da belirlemişlerdir. Günümüzde yapılan bilimsel çalışmalarda genel olarak bir bütünlük bulunsa da bazı karakterler farklı yazılmıştır. Bunlar, “"̃̃, y, â, â, ù, û, i, î" karakterleri ile dilimizde kullanılan Arapça ve Farsça kelimelerle oluşan özel isimler, bileşik kelimeler, coğrafya adları, kitap isimleri vb. kelimelerdir.

Belirlenen harflerde küçük farkll1ıklar olsa da bunlar üzerinde birçok çalı̧ma yapılmış ve epey mesafe alınmıştır. Bu farklılıklar nedeniyle, Osmanlı Türkçesi ile yazılan sözlüklerin yanı sıra, Farsça Türkçe yazılan sözlüklerin bugünkü alfabeye aktarılması sırasında, Türkçede kullanılan Arapça ve Farsça kökenli bazı kelimeler ile bu kelimelerin açıklanmalarının çeviri yazıya aktarımında bütünlük görülmemektedir. Bu makalede, belirlenen sözlüklerde tespit edilen yazım farkl1lıları gösterilerek bilimsel çalş̧malar ile kurum ve kuruluşlar tarafından yapılan yayınlarda çeviri yazı ve yazım birliğinin sağlanmasının önemine vurgu yapilacaktır.

Anahtar Kelimeler: Çeviri yazı, İmla, Osmanlı Türkçesi, Sözlük, Farsça-Türkçe Sözlük. 


\title{
Certain Evaluations and Resolutions upon Translation, Writing and Spelling Issues Encountered in Persian-Turkish and Ottoman-Turkish Dictionaries
}

\begin{abstract}
As the interest of the Western scholars ascended upon the East, transcription has become one of the most significant topics, which came forth as an issue with the adoption of the Latin alphabet on 3 November 1928 in Turkey. The change of centuries-old alphabets with another writing system brings up some problems naturally. Transcription is considered among these problems. The Western scholars address the issue that it began with the Meninski's dictionary Thesaurus Linguarum Orientalium, which involves the Latin equivalents of Arabic, Persian and Turkish words, and concludes the issue with the publication of the transcription system in 1894 prepared by The Royal Asiatic Society established in London by a commission for the Sanskrit and Arabic alphabet.
\end{abstract}

The necessity of changes and improvements of the Ottoman alphabet put forward in Tanzimat Period since the inadequacies and deficiencies of the alphabet required. Various researches and studies were carried out by scholars on the subject. Türkçede Arabî ve Latin Harfleri ve Imlâ Meseleleri by Avram Galanti was one of the first works in the Republic of Turkey on the issue of Arabic and Latin alphabets that was written in 1925 . The transition to the Latin alphabet, which started to be bruited within the Tanzimat Period, accelerated with the establishment of the Republic and ended with the acceptance of the Latin alphabet in 1928.

Based on the studies conducted in the West, the spelling symbols / letters suitable for the Turkish sound harmony of the translation text were determined in terms of bot transcription and transliteration. In this regard, the modern Turkish transfer process in academic studies on Ottoman Turkish in Turkey are conducted by considering the Encyclopedia of Islam which is 2 different studies within the same title from the Ministry of Education and Türkiye Diyanet Foundation. In addition, some public institutions, organizations and universities have also determined their own writing rules based on these two works. Although there is an overall unity in scientific studies conducted today, some characters are written differently. The differences are seen at the characters of " $\tilde{n}, \eta \bar{a}, \bar{a}, \bar{u}, \hat{u}, \bar{i}, \hat{\imath}$ ”, special names, compound words, geographical names, book names, etc., which are formed with Arabic and Persian words used in our language. 
Although there are minor differences in the letters identified, many studies have been done on them and considerable distance has been taken. Due to these differences, while translating dictionaries written in Ottoman Turkish to dictionaries written in Persian-Turkish into today's alphabet, some words of Arabic and Persian origin used in Turkish and the explanations of these words are not confronted in translation. In this article, it will be emphasized the importance of providing unity of translation and spelling in scientific studies and publications made by institutions and organizations by showing the spelling differences determined in the dictionaries.

Keywords: Transcription, Dictation, Ottoman Turkish, Dictionary, Persian-Turkish Dictionary.. 


\section{Giriş}

7 ranskripsiyon/çeviri yazı konusu Batıllıarın Doğuya olan ilgi ve ala1 kalarıyla ortaya çıkmıştır. Yaklaşık XI. yüzyılda seyyahlar tarafından başlatılan Doğuyu keşfetme isteği, o toplumun dilini öğrenme gerekliliğini beraberinde getirmiştir. XVII. yüzyılda Meninski tarafından telif edilip Arapça, Farsça ve Türkçe sözcüklerin Latince karşılıklarını içeren Thesaurus Linguarum Orientalium adlı lügat (MEB İA 1941: IV), çeviri yazı konusunun bu dönemden itibaren gündeme geldiğini düşündürmektedir. Bu dönemden itibaren başlayan süreç, Londra’da kurulan The Royal Asiatic Society'nin Sanskrit ve Arap alfabesi için bir komisyona hazırlattığı transkripsiyon sisteminin 1894'te yayımlanmasıyla (Durmuş 2002: 307) resmî bir hâl almıştır. Daha sonra Batı dilbilimcileri tarafından yapılan çalışmalar ve incelemeler neticesinde çeviri yazı meselesi kendi içlerinde belli ölçüde çözüme kavuşturulduğu ifade edilmiştir (Ünver 2008: 2).

Batı dünyasında hâl böyleyken Osmanlı Devleti Arap alfabesini kullanıordu. Osmanlı Devleti'nin sonlarına doğru özellikle de Tanzimat Dönemi’nde alfabenin yetersizlikleri ve eksiklikleri olduğu düşüncesiyle değiştirilmesi ya da 1slah edilmesi gündeme gelmiş ve bu husus için bilim adamları tarafindan araştırma ve çalışmalar yapılmıştır (Togan 1981: XVIII; Akçay 2007: 4-16, Ulu 2017: 277-302; Anhegger 2017: 136-142). Türkiye Cumhuriyeti'nde Arap ve Latin alfabesi meselesiyle ilgili yazılan ilk eserlerden biri 1925 yılında Avram Galanti tarafindan Arap alfabesiyle yazılan Türkşede Arabî ve Latin Harfleri ve İmlâ Meseleleri adlı eserdir. Galanti bu eserinde Arap alfabesinin Latin alfabesine karşıllk gelen seslerini tarihi açıdan belirtmeye çalı̧̧ış ve benzer seslerle ilgili yazım konularından bahsetmiştir. Tanzimat'la birlikte konuşulmaya başlayan Latin alfabeye geçiş konusu Cumhuriyetin kurulmasıyla hızlanmış ve 1928'de Latin alfabesinin kabulüyle sonuçlanmıştır.

Alfabenin değişmesiyle birlikte eğitim süreci de hızlanmıştır. Bu kapsamda İstanbul'da Devlet Matbaası tarafindan 1928 yılında millet mektepleri ve halk dershaneleriyle harf kurslarında okutulmak için Millî Talim ve Terbiye Heyeti'nce hazırlanan Alfabe, Kirầat, Yazı ve Imlâ Tedrîsi Usûlü adlı kitap yayımlanmıştır.

Ayrıca İstanbul'da 1928'de Dil Encümeni tarafından hazırlanan ve İstanbul Devlet Matbaasında basılan İmlâ Lûgati adıyla bir sözlük yayımlanmıştır. Bu sözlüğün mukaddimesinde Türkçe imla/yazım ile birlikte Türkçede kullanılan yabancı kelimelerin nasıl yazılacağı ile ilgili bilgilere yer verilmiştir. Bura- 
da heyet, yabancı kelimelerin Türk fonetiğine uygun olarak yazılması kurallarından, ünsüz değişmeleri ve inceltme işareti olarak $\left(^{(}\right)$işaretinin nerede nasıl kullanılacağından ve diğer yazım kurallarından (1928: X-XIII) bahsetmiştir. Millî Eğitim Bakanlığı tarafından yayımlanan İslâm Ansiklopedisìnde Arap alfabesi ile yazılan metinlerde çeviri yazı ve yazım ilkeleri belirlenmiş ve burada belirlenen esaslar üzerinden bilimsel çalışmalar yapilmı̧s ve yayımlanmıştır. Burada Türkçede kullanılan Arapça ve Farsça kelimeler madde başı yapılırken, kelime içerisindeki uzatma harfleri ( $\left.{ }^{(}\right)$şapkalı yazılmış, sonra çeviri yazı sistemi uygulanmıştır. Metin içerisinde Türkçe seslere karşılık gelen harfler hariç, Batıda uygulanan çeviri yazı simgeleri kullanılmıştır. Örneğin, med harfleri olarak bilinen uzatmalar " $\bar{a}$ ", " $\overline{\mathrm{u}}$ " ve "ī" şeklinde yazılmıştır.

Çeviri yazı konusunda yayımlanan en önemli çalışmalardan bir diğeri de İstanbul Üniversitesi Edebiyat Fakültesince hazırlanan ve Millî Eğitim Bakanlığı tarafindan 1946'da İstanbul'da basılan Türk İlmî Transkripsiyon Kılavuzu adlı eserdir. Adından da anlaşılacağı üzere bu çalışma, ülkemizde yapılan bilimsel araştırma ve çalışmalara rehberlik etmiş ve yol gösterici olmuştur.

Türkiye Diyanet Vakfı tarafından yayımlanan İslâm Ansiklopedisìnde Arapça ve Farsça asıllı özel isimlerin okunuşunda ve Arapça ile Farş̧a kurallara göre yapılan kitap isimlerinde kendine has usuller belirlenmiş ve Arap ve Fars dili ile yazılmış kitap, dergi ve makale adlarında uzatma işareti olarak $\left(^{(}\right)$şapka işareti kullanılmıştır. Ayrıca özel isimler ve cins isimler başlı̆̆ı altında diğer yazım kuralları tespit edilerek Ansiklopedi içerisinde uygulanagelmiştir.

Sonuçta Millî Ĕgitim Bakanlığı tarafından yayımlanan İslâm Ansiklopedisi ile Türkiye Diyanet Vakfı tarafindan yayımlanan İslâm Ansiklopedisinde uzatma harflerinin yazımında ayrılık olmuş, Millî Eğitim Bakanlığı tarafından yayımlanan ansiklopedide uzatma harflerinde "ā", “ū” ve “i” şeklinde yazılırken, Diyanet Vakfi tarafından yayımlanan ansiklopedide ise "â", “ı”” ve "û" şekli tercih edilmiştir. Böylece her iki ansiklopedideki yazım farklılıkları üniversitelerdeki bilimsel çalı̧̧malara ve kamu kurumları tarafından yapılan yayınlara da yansımı̧̧ır.

Ayrıca bazı kurumlar, dernek ve örgütler yayımladıkları eser ve makalelerde bu iki ansiklopediden hareketle kendi yazım kurallarını belirlemişlerdir. Türk Dil ve Edebiyat Derneği Dil ve Edebiyat Dergisi, Ankara Üniversitesi İlahiyat Fakültesi Dergisi, Atatürk Üniversitesi Türkiyat Araştırmaları Enstitüsü Dergisi, Turkish Studies, Türk Tarih Kurumu bunlardan bazılarıdır. 
Dilimizde kullanılan Arapça ve Farş̧a kelimelerin yazımı konusunda, İLESAM tarafından 17-18 Ocak 1992 tarihinde düzenlenen "I. Eski Türk Edebiyatı Kolokyumu"nda sunulan bildirilerden hareketle genişletilen ve Turkish Studies’in İmlâ Özel Sayı'sında yayımlanan İsmail Ünver'in "Çevriyazıda Yazım Birliği Üzerine Öneriler” adlı çalışması önemli bir değerlendirmedir.

Prof. Dr. Zeynep Korkmaz da çeviri yazı konusunu "Türlü nedenlerle daha tam olarak rayına oturmamış bulunan imla konusunun, farklı yazım biçimlerinden arındırılarak, bilimsel temelde bir birliğe ulaştırılması...(2009: CXV)" şeklindeki önerisiyle dile getirmiş, Türkiye Diyanet Vakfi İslâm Ansiklopedisi heyeti ise, I. cildde imla esasları başlı̆̆ında “Türkçenin bugünkü imlâsı herkesin benimseyeceği bir çözüme henüz kavuşturulmadığından” bahisle ansiklopedide uygulanacak yazım esaslarını tespit etmiş ve uygulayagelmiştir.

\section{Çeviri Yazı}

İstanbul Üniversitesi Edebiyat Fakültesince hazırlanan Türk İlmî Transkripsiyon Kılavuzu adlı kitapçıkta, çeviri yazı için "Türk milletinin bugüne kadar kullanmış olduğu muhtelif alfabelerle tespit edilmiş eserlerini, icabında asıllarına en uygun bir şekilde, yâni bütün ses işâretlerinin ve imlâ hususiyetlerinin muhafazasını te'min etmek suretiyle, bugünkü alfabemizle tam ve doğru bir transkripsiyonunu te'min etmek" (1946: 3) şeklinde geniş bir tanım yapılmışken Yusuf Ziya Kavakçı tarafından da "bir dilin ibarelerini kendi alfabesiyle değil de başka bir dilin alfabesiyle yazmak” (Kavakçı: 122) şeklinde kısa bir tanım yapılmıştır.

Türk Dil Kurumunun "bir yazıyı bütün ses inceliklerini belirterek başka bir alfabeye çevirme yolu” olarak tanımladığı çeviri yazı, Türkiye Diyanet Vakfi İlâm Ansiklopedisinde "Bir alfabede yer alan harflerin bazı özel işaretler ilâvesiyle başka bir alfabenin karakterlerine çevrilmesi” olarak tanımlanmaktadır. Bir dilin bütün sesleri diğer dilin alfabesiyle tam olarak karşılanmayabilir. Ĕğer bir dilde yazılanlar başka bir alfabe ile yazıldığında her harfe karşılık bir harf geliyorsa bu tanıma transkripsiyon; eğer tüm sesler karşılanmıyor, ek işaretler gerekiyorsa bu tanıma da transliterasyon (Kavakç1: 122-123) denilmektedir. Bu bağlamda yukarıda çeviri yazı ile ilgili tanımlar hem transkripsiyonu hem de transliterasyonu kapsamaktadır. Neticede çeviri yazı, bir dilin alfabesindeki tüm seslerin bazı özel harfler ilavesiyle başka bir dilin alfabesine aktarılma işidir.

Bugün hem Batı'da hem de Doğu'da Arap alfabesinin Latin alfabesine aktarımı için çeviri yazı sistemi kullanılmaktadır. Avrupa'da ve Türkiye'de bilimsel yayınlarda kullanılan bazı çeviri yazı alfabeleri aşağıdaki tabloda görülmektedir. 


\section{A. Sesliler}

\begin{tabular}{|c|c|c|c|c|c|c|c|c|c|c|c|c|c|c|c|}
\hline $\begin{array}{l}\text { Arap/Fars } \\
\text { Alfabesi }\end{array}$ & i & $!$ & i & $\therefore$ & $i$ & او او & ي & ي، ئى & وُُ، واو & & - & '. & 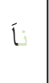 & | - كي & $96^{3}$ \\
\hline $\begin{array}{l}\text { A Concise } \\
\text { Encylopedia of } \\
\text { Islam* }\end{array}$ & & & & , & â & $\hat{\mathrm{u}}$ & $\hat{1}$ & $\hat{\imath}$ & û & $\mathrm{a}$ & $\mathrm{i}$ & $\mathrm{u}$ & & & \\
\hline $\begin{array}{l}\text { Die Buchstaben } \\
\text { des Arabischen } \\
\text { Alphabetes** }\end{array}$ & $\mathrm{a}, \mathrm{e}$ & $\mathrm{i}$ & $\mathrm{u}, \mathrm{o}$ & , & $\overline{\mathrm{a}}$ & $\overline{\mathrm{u}}$ & $\overline{\mathrm{i}}$ & $\overline{\mathrm{i}}$ & $\overline{\mathrm{u}}$ & $\mathrm{a}, \mathrm{e}$ & $\mathrm{i}$ & $\mathrm{u}, \mathrm{o}$ & & & \\
\hline $\begin{array}{l}\text { Arabic } \\
\text { Romanization*** }\end{array}$ & $\mathrm{a}$ & $\mathrm{i}$ & $\mathrm{u}$ & , & $\overline{\mathrm{a}}$ & $\overline{\mathrm{u}}$ & $\overline{1}$ & $\overline{1}$ & $\overline{\mathrm{u}}$ & $\mathrm{a}$ & $\mathrm{i}$ & $\mathrm{u}$ & $\overline{\mathrm{a}}$ & $\overline{1}$ & $\overline{\mathrm{u}}$ \\
\hline $\begin{array}{l}\text { Yeni Tarama } \\
\text { Sözlüğü }\end{array}$ & $\mathrm{a}, \mathrm{e}$ & $1, \mathrm{i}$ & $\begin{array}{l}\mathrm{u}, \ddot{\mathrm{u}} \\
\mathrm{o}, \mathrm{o}\end{array}$ & , & $\overline{\mathrm{a}}$ & $\overline{\mathrm{u}}$ & $\overline{\mathrm{i}}$ & $\overline{\mathrm{i}}$ & $\overline{\mathrm{u}}, \overline{\mathrm{o}}$ & $\mathrm{a}$ & $\mathrm{i}$ & $\mathrm{u}$ & $\overline{\mathrm{a}}$ & $\overline{\mathrm{i}}$ & $\overline{\mathrm{u}}$ \\
\hline TürkçeSözlük & $\mathrm{a}$ & $\mathrm{i}$ & $\mathrm{u}$ & $\cdot$ & $\bar{a}$ & $\overline{\mathrm{u}}$ & $\overline{\mathrm{i}}$ & $\overline{\mathrm{i}}$ & $\overline{\mathrm{u}}, \overline{\mathrm{o}}$ & $\mathrm{a}$ & $\mathrm{i}$ & $\mathrm{u}$ & $\overline{\mathrm{a}}$ & $\overline{\mathrm{i}}$ & $\overline{\mathrm{u}}$ \\
\hline $\begin{array}{l}\text { Türk İlmî } \\
\text { Transkripsiyon } \\
\text { Kılavuzu }\end{array}$ & $\mathrm{a}$ & $\mathrm{i}$ & $\mathrm{u}$ & $\cdot$ & $\overline{\mathrm{a}}$ & $\overline{\mathrm{u}}$ & $\overline{\mathrm{i}}$ & $\overline{\mathrm{i}}$ & & a & $\mathrm{i}$ & $\mathrm{u}$ & $\overline{\mathrm{a}}$ & $\overline{\mathrm{i}}$ & $\overline{\mathrm{u}}$ \\
\hline $\begin{array}{l}\text { MEB İslâm } \\
\text { Ansiklopedisi }\end{array}$ & $\mathrm{a}$ & 1 & o & , & $\overline{\mathrm{a}}$ & $\overline{\mathrm{u}}$ & $\overline{\mathrm{i}}$ & \multicolumn{5}{|c|}{ Türkçe Telaffuzda } & â & $\hat{\imath}$ & $\hat{\mathrm{u}}$ \\
\hline $\begin{array}{l}\text { Diyanet } \\
\text { Vakfi İslâm } \\
\text { Ansiklopedisi }\end{array}$ & $\mathrm{a}, \mathrm{e}$ & $\mathrm{i}$ & $\mathrm{u}$ & $\cdot$ & â & $\hat{\mathrm{u}}$ & $\hat{\imath}$ & $\hat{\imath}$ & û & a & $\mathrm{i}$ & $\mathrm{u}$ & â & $\hat{1}$ & $\hat{\mathrm{u}}$ \\
\hline $\begin{array}{l}\text { Ankara } \\
\text { Üniversitesi } \\
\text { İlahiyat } \\
\text { Fakültesi } \\
\text { Dergisi }\end{array}$ & $\mathrm{e}, \mathrm{a}$ & $\mathrm{i}$ & $\mathrm{u}$ & , & $\overline{\mathrm{a}}$ & $\overline{\mathrm{u}}$ & $\overline{1}$ & $\overline{1}$ & $\overline{\mathrm{u}}$ & $\mathrm{e} / \mathrm{a}$ & $\mathrm{i}$ & $\mathrm{u}$ & $\overline{\mathrm{a}}$ & $\overline{1}$ & $\overline{\mathrm{u}}$ \\
\hline
\end{tabular}

* Gordon D. Newby, A Concise Encylopedia of Islam, (England: Oneworld Publications, 2004), IX-X.

** Bu çeviri yazı alfabesi, Roma'da yapılan "19. Uluslararası Roma Oryantalist Konresi”nde kararlaştırılmıştır, bk. Carl Brockelmann vd., "Die Transliterasyon der arabischen Schrift in ihrer Anwendung auf die Hauptliteratursprahen der İslâmischen Welt” (Leipzig: Denkschrift dem 19. İnternationalen Orietalistenkongre $\beta$ in Rom, 1935), 9.

*** Bu çeviri yazı alfabesi 2012 yilında, The Library of Congress (USA) tarafindan güncellenmiştir. 


\section{B. Sessizler}

\begin{tabular}{|c|c|c|c|c|c|c|c|c|c|c|c|c|c|c|c|c|c|}
\hline $\begin{array}{c}\text { Arap/Fars } \\
\text { Alfabesi }\end{array}$ & ب & ب & ت &  & ج & ج & $\tau$ & $\dot{\tau}$ & د & j & נ & j & $j$ & س & ش & ص & ض \\
\hline $\begin{array}{c}\text { A Concise } \\
\text { Encylopedia of } \\
\text { Islam }\end{array}$ & $\mathrm{b}$ & & $\mathrm{t}$ & th & $\mathrm{j}$ & & ḥ & $\mathrm{kh}$ & $\mathrm{d}$ & $\mathrm{dh}$ & $r$ & Z & & $\mathrm{S}$ & sh & Ș & ḍ \\
\hline $\begin{array}{c}\text { Die Buchstaben } \\
\text { des Arabischen } \\
\text { Alphabetes }\end{array}$ & $\mathrm{b}$ & $\mathrm{p}$ & $\mathrm{t}$ & $\underline{\mathbf{S}}$ & & & hạ & $\underline{\mathrm{h}}$ & $\mathrm{d}$ & $\underline{\mathrm{Z}}$ & $r$ & Z & & $\mathrm{S}$ & & Ș & \\
\hline $\begin{array}{c}\text { Arabic } \\
\text { Romanization }\end{array}$ & $\mathrm{b}$ & $\mathrm{p}$ & $\mathrm{t}$ & th & $\mathrm{j}$ & $\begin{array}{l}\mathrm{ch} / \\
\mathrm{zh}\end{array}$ & ḥ & $\mathrm{kh}$ & $\mathrm{d}$ & $\mathrm{dh}$ & $\mathrm{r}$ & Z & $\mathrm{zh}$ & $\mathrm{S}$ & sh & Ș & ḍ \\
\hline $\begin{array}{c}\text { Türk Dil } \\
\text { Kurumu Tarama } \\
\text { Sözlüğü }\end{array}$ & $\mathrm{b}$ & $\mathrm{p}$ & $\mathrm{t}$ & $\underline{\mathbf{S}}$ & $\mathrm{c}$ & ç & ḥ & $\underline{\mathrm{h}}$ & $\mathrm{d}$ & $\underline{\mathrm{Z}}$ & $r$ & Z & $\mathrm{j}$ & $\mathrm{S}$ & Ş & Ș & ḍ \\
\hline $\begin{array}{c}\text { Türk Dil } \\
\text { Kurumu } \\
\text { Türkçe Sözlük }\end{array}$ & $\mathrm{b}$ & $\mathrm{p}$ & $\mathrm{t}$ & $\underline{\mathbf{S}}$ & $\mathrm{c}$ & ç & ḥ & $\mathrm{h}$ & $\mathrm{d}$ & $\underline{\mathrm{Z}}$ & $r$ & $\mathrm{Z}$ & $\mathrm{j}$ & $\mathrm{S}$ & Ş & Ș & d \\
\hline $\begin{array}{c}\text { Türk İlmî } \\
\text { Transkripsiyon } \\
\text { Kilavuzu }\end{array}$ & $\mathrm{b}$ & $\mathrm{p}$ & $\mathrm{t}$ & $\underline{\mathbf{S}}$ & $\mathrm{c}$ & ç & hạ & $\mathrm{h}$ & $\mathrm{d}$ & $\underline{\mathrm{Z}}$ & $r$ & $\mathrm{Z}$ & & $\mathrm{S}$ & Ş & Ș & $\stackrel{d}{d}$ \\
\hline $\begin{array}{c}\text { MEB İslâm } \\
\text { Ansiklopedisi }\end{array}$ & $\mathrm{b}$ & $\mathrm{p}$ & $\mathrm{t}$ & $\underline{\mathbf{S}}$ & $\mathrm{c}$ & ç & hạ & $\mathrm{h}$ & $\mathrm{d}$ & $\underline{\mathrm{Z}}$ & $r$ & Z & $\mathrm{j}$ & $\mathrm{S}$ & Ş & Ṣ & ḍ \\
\hline $\begin{array}{c}\text { Diyanet } \\
\text { Vakfı İslâm } \\
\text { Ansiklopedisi }\end{array}$ & $\mathrm{b}$ & $\mathrm{p}$ & $\mathrm{t}$ & $\underline{\mathbf{S}}$ & $\mathrm{c}$ & ç & hạ & $\mathrm{h}$ & $\mathrm{d}$ & $\underline{\mathrm{Z}}$ & $r$ & $\mathrm{Z}$ & $\mathrm{j}$ & $\mathrm{S}$ & Ş & Ș & d \\
\hline $\begin{array}{c}\text { Ankara } \\
\text { Üniversitesi } \\
\text { İlahiyat } \\
\text { Fakültesi Dergisi }\end{array}$ & $\mathrm{b}$ & & $\mathrm{t}$ & $\underline{\mathbf{S}}$ & $\mathrm{c}$ & & hạ & $\mathrm{h}$ & $\mathrm{d}$ & $\underline{\mathrm{Z}}$ & $r$ & $\mathrm{Z}$ & & $\mathrm{S}$ & Ş & Ș & $\stackrel{d}{d}$ \\
\hline
\end{tabular}




\begin{tabular}{|c|c|c|c|c|c|c|c|c|c|c|c|c|c|c|c|c|}
\hline $\begin{array}{c}\text { Arap/Fars } \\
\text { Alfabesi }\end{array}$ & b & ظ & $\varepsilon$ & $\dot{\varepsilon}$ & ف & ق & 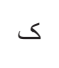 & s & ك،كث & كن & J & r & ن & و & 。 & ى \\
\hline $\begin{array}{l}\text { A Concise Enc- } \\
\text { ylopedia of Islam }\end{array}$ & $\underline{t}$ & Z & ' & gh & f & $q$ & & & & & 1 & $\mathrm{~m}$ & $\mathrm{n}$ & W & $\mathrm{h}$ & $\mathrm{y}$ \\
\hline $\begin{array}{l}\text { Die Buchstaben } \\
\text { des Arabischen } \\
\text { Alphabetes }\end{array}$ & $\mathrm{t}$ & $\mathrm{Z}$ & ' & $\dot{\mathrm{g}}$ & f & $\mathrm{q}$ & $\mathrm{k}, \mathrm{g}, \hat{\mathrm{j}}$ & - & & & 1 & $\mathrm{~m}$ & $\mathrm{n}$ & $\mathrm{V}$ & $\mathrm{h}$ & $\mathrm{y}$ \\
\hline $\begin{array}{l}\text { Arabic } \\
\text { Romanization }\end{array}$ & $\mathrm{t}$ & $\mathrm{Z}$ & ' & gh & $\mathrm{f}$ & $\mathrm{q}$ & $\mathrm{k}$ & $\mathrm{g}$ & $\tilde{\mathrm{n}}$ & & 1 & $\mathrm{~m}$ & $\mathrm{n}$ & W & $\mathrm{h}$ & $\mathrm{y}$ \\
\hline $\begin{array}{l}\text { Türk Dil Kurumu } \\
\text { Tarama Sözlüğü }\end{array}$ & t & $\mathrm{Z}$ & ' & $\dot{\mathrm{g}}$ & $\mathrm{f}$ & $\mathrm{k}$ & $\mathrm{k}, \mathrm{g}$ & $\mathrm{g}$ & $\tilde{\mathrm{n}}, \mathrm{\eta}$ & $\widehat{\mathrm{ng}}$ & 1 & $\mathrm{~m}$ & $\mathrm{n}$ & $\mathrm{V}$ & $\mathrm{h}$ & $\mathrm{y}$ \\
\hline $\begin{array}{l}\text { Türk Dil Kurumu } \\
\text { Türkçe Sözlük }\end{array}$ & $\mathrm{t}$ & Z & ' & $\dot{\mathrm{g}}$ & $\mathrm{f}$ & $\mathrm{k}$ & $\mathrm{k}$ & $\mathrm{g}$ & $\tilde{\mathrm{n}}$ & & 1 & $\mathrm{~m}$ & $\mathrm{n}$ & $\mathrm{V}$ & $\mathrm{h}$ & $\mathrm{y}$ \\
\hline $\begin{array}{l}\text { Türk İlmî } \\
\text { Transkripsiyon } \\
\text { Kılavuzu }\end{array}$ & $\mathrm{t}$ & Z & ' & $\dot{\mathrm{g}}$ & f & $\mathrm{k}$ & $\mathrm{k}$ & $\mathrm{g}$ & $\tilde{\mathrm{n}}$ & $\widehat{\mathrm{ng}}$ & 1 & $\mathrm{~m}$ & $\mathrm{n}$ & $\mathrm{V}$ & $\mathrm{h}$ & $\mathrm{y}$ \\
\hline $\begin{array}{l}\text { MEB İslâm } \\
\text { Ansiklopedisi }\end{array}$ & $\mathrm{t}$ & $\mathrm{Z}$ & ' & $\dot{\mathrm{g}}$ & $\mathrm{f}$ & $\mathrm{k}$ & $\mathrm{k}$ & $\mathrm{g}$ & $\tilde{\mathrm{n}}$ & & 1 & $\mathrm{~m}$ & $\mathrm{n}$ & $\mathrm{V}$ & $\mathrm{h}$ & $\mathrm{y}$ \\
\hline $\begin{array}{l}\text { Diyanet } \\
\text { Vakfi İslâm } \\
\text { Ansiklopedisi }\end{array}$ & $\mathrm{t}$ & Z & ' & $\dot{\mathrm{g}}$ & f & $\mathrm{k}$ & $\mathrm{k}$ & $\mathrm{g}$ & $\tilde{\mathrm{n}}$ & & 1 & $\mathrm{~m}$ & $\mathrm{n}$ & $\mathrm{v}$ & $\mathrm{h}$ & $\mathrm{y}$ \\
\hline $\begin{array}{l}\text { Ankara Üniversite- } \\
\text { si İlahiyat Fakültesi } \\
\text { Dergisi }\end{array}$ & $\mathrm{t}$ & $\mathrm{Z}$ & ' & $\dot{\mathrm{g}}$ & f & k & $\mathrm{k}$ & & & & 1 & $\mathrm{~m}$ & $\mathrm{n}$ & $\mathrm{V}$ & $\mathrm{h}$ & $\mathrm{y}$ \\
\hline
\end{tabular}

A Concise Encylopedia of Islam'da " "ث، ج، خ، ذ، ش، غ، ق" harfleri sirayla “th, j, kh, dh, sh, gh, q” harfleriyle ve uzatma harfleri de “â, û ve î” şeklinde gösterilmiştir. Türkçe ve Farsça sesler için herhangi bir harf belirlenmemiştir.

Carl Brockelmann ve ekibi tarafindan 1935 yılında "Roma 19. Uluslararası Oryantalist Kongresi”nde sunulan bildiride Farsça ve eski Türk alfabesindeki

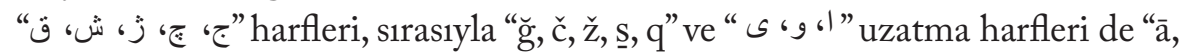
ù ve $\bar{i}$ ” şeklinde belirtilmiştir.

The Library of Congress 2012 yılında Arabic Romanization çeviri yazı alfabesinde “ "خ " harfleri, sirasiyla “th, j, ch/zh, kh, dh, zh, sh, gh, q" harfleriyle ve elif-i meksûre ise (⿶), "á” işareti ile gösterilmiştir.

Tabloda da görüldüğü üzere uzatma harflerinde farklı yazım karakterleri kullanılmıştır. Ülkemizde yapılan bilimsel çalışmalarda ise genel olarak bir bütünlük bulunsa da bazı karakterler farklı yazılmaktadır. Bunlar, “ñ, y, à, â, ù, û, $\overline{\mathbf{i}}, \hat{\imath}$ ” karakterleri ile dilimizde kullanılan Arapça ve Farsça kelimelerle oluşan özel isimler, bileşik kelimeler, coğrafya adları, kitap isimleri vb. kelimelerdir. Bazı kurumlar ve dergiler tarafından yayımlanan her bir çalışmada bu karakterleri görmek mümkündür. Bir önceki çalışmada “ñ” karakteriyle yazılan ses, 
daha sonraki başka bir çalışmada " $y$ " şeklinde yazılmış veya bir çalı̧manın içinde " $\bar{u}$ " şeklinde yazılan harf, aynı çalışma içinde "û" şeklinde de yazılmıştır.


"th, j, kh, dh, sh, gh, q" karakterleriyle karşılanırken, Türkçe çeviri yazı siste-

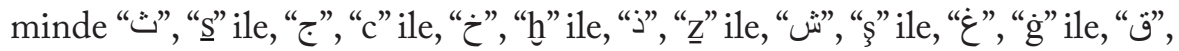
"ḳ” ile karşılanmıştır. Bu karakterlerin yazımında birliktelik sağlanmakla bir-

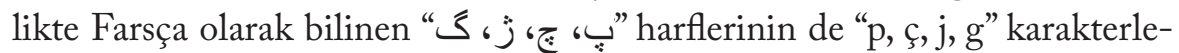
riyle gösterilmesinde de bir farkll1ık olmamıştır. Türkçe çeviri yazı sisteminde


“â, û, î" şeklinde yazılması dışında bir yazım farklılığı bulunmamaktadır.

Bunlarla birlikte başka bir konu daha ortaya çıkmaktadır. O da yapılan bilimsel çalışmaların yayın olarak basılmasıdır. Kurumlar, bilimsel çalışmaların basılması esnasında kendi yazım ilkelerini belirleyebilmektedir. Bu ilkelerin temelde bir bütünlük içerisinde olması esastır. Ancak yapılan yayınlarda bu esasın olmadığı görülmektedir.

\section{Farsça-Türkçe Sözlükler}

Sözlük, temel başvuru kaynaklarından biridir. Türklerde sözlük denildiğinde akla ilk gelen Kâşgarlı Mahmud ve onun eseri olan Divanü Lügati't-Türk'tür. Kâşgarlı Mahmud, Türklerde sözlükçülüğün temelini oluşturmuştur. Sözlük bir dilin kelimelerini kendi sözcükleriyle açıkladığı gibi başka bir dil ya da dillerin kelimelerini de açıklayabilir. Bir sözlük, başka bir dilin sözcüklerini açıklıyorsa iki dilli, birden fazla dili açıklıyorsa çok dilli sözlük diye adlandırılır. Bu çalışmada örnek alınan sözlük türü, iki dilli olarak adlandırılan Farsça-Türkçe sözlüktür. Fakat burada anlatılan husus, bugüne kadar yazılan sözlükler ve bunların mahiyetleri değil, eski Türk alfabesi ile yazılmış ve üzerinde çalı̧̧ma yapılarak Türk Dil Kurumu tarafindan basımı yapılan Farsça-Türkçe sözlüklerin çeviri yazı alfabesi açısından yazım şeklidir. Bununla birlikte kamu kurumu, kuruluş ve kişilerce bastırılan sözlüklerden de örnekler verilerek farkl11ıklar gösterilecektir.

Türk Dil Kurumu “Türkiye Türkçesi Sözlükleri Projesi” kapsamında Sözlük Bilim ve Uygulama Kolu tarafindan çalışmalar başlatmış ve bu doğrultuda Mütercim Âsım Efendi tarafindan hazırlanan Burbân-ı Katı adlı Farsça-Türkçe sözlük, Mürsel Öztürk ve Derya Örs tarafindan Latin alfabesine aktarılarak 2009 y1lında Türkçeye kazandırılmıştır. Bu sözlüğün dışında Ni'met'ullâh Ahmed tarafindan telif edilen ve Türkiye Türkçesinin Tarihsel Sözlüğü Projesi kapsamında taramaya alınan Lügat-i Nimet’ullâh adlı Fars- 
ça-Türkçe sözlük de Adnan İnce tarafından çalışılmış ve Türk Dil Kurumu tarafından 2015 yılında yayımlanmıştır. Bu iki sözlüğün dışında alfabetik olarak hazırlanan ilk sözlüklerden biri olan ve Lütfullah b. Ebî Yûsuf (Lütfullah Halîmî) tarafından yazılan Lügat-i Halîmı̂ adlı Farsça Türkçe sözlük ise Adem Uzun tarafından hazırlanmış ve Türk Dil Kurumu tarafından 2013 yılında yayımlanmıştır. Aşağıda bu sözlüklerin çeviri yazı ile uzatma harfleri, Arapça-Farsça özel isimler ve yer adları, tamlamalar ve madde başlarının yazım farkları gösterilmiştir.

\section{Lügat-i Halîmî}

Bu sözlük, XV. yüzyılda Lütfullah Halîmî tarafindan Farsça-Türkçe olarak yazılmış ilk alfabetik sözlüklerden biridir (Uzun 2013). Bu sözlükte Türkiye Diyanet Vakfi tarafindan yayımlanan İslâm Ansiklopedisinndeki çeviri yazı alfabesi esas alınmıştır.

\section{Lügat-i Ni’metu'llâb}

Bu sözlük, XVI. yüzyılın ortalarına doğru Anadolu'da asıl adı Halil Sufî olarak bilinen Ni’met'ullâh tarafindan yazılmı̧̧ önemli bir eserdir (İnce 2015). Bu sözlükte Millî Eğitim Bakanlığı tarafından yayımlanan İslàm Ansiklopedisindeki çeviri yazı alfabesi esas alınmıştır.

\section{Burbân-ı Katı}

Bu sözlük, XVII. yüzyılda Muhammed Hüseyin b. Halef et-Tebrizî tarafindan telif edilen Farsça bir eserdir. Bu eser Mütercim Âsım Efendi (1755-

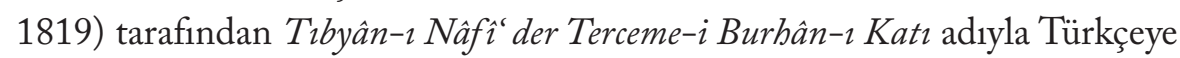
çevrilmiştir (Öztürk, Örs 2009). Bu sözlüğün Latin alfabesine aktarımında Türk Dil Kurumu İmlâ Kılavuzu (Ankara 1996) esas alınmıştır.

Bu sözlüklerin çeviri yazı ve yazım şekillerinden bazı örnekler aşağıdaki tabloda görülmektedir. 


\begin{tabular}{|c|c|c|c|}
\hline & Lügat-i Halîmî & Lügat-i Niłmetu'llâb & Burhân-ı Katı \\
\hline İmla & Çeviri yazı & Çeviri yazı & Yazım Kılavuzu* \\
\hline Dizin & Eski alfabe & Eski alfabe & Yeni alfabe** \\
\hline Madde başı & Kalın/bold & Kalın/bold & Kalın/bold \\
\hline Madde başı okunuş & Eğik/italik & Kalın/bold & (düz) \\
\hline Uzatma harfleri & $\hat{a}, \hat{u}, \hat{i}$ & $\overline{\mathrm{a}}, \overline{\mathrm{u}}, \overline{\mathrm{i}}$ & $\hat{\mathrm{a}}, \hat{\mathrm{u}}, \hat{\mathrm{i}}$ \\
\hline Birleşik fiiller & Bir karakter boşluk & Bir karakter boşluk & \\
\hline Birleşik isimler & (-) tire ile ayrılmış & Bitişik yazılmış & \\
\hline $\begin{array}{l}\text { Yapım ekli keli- } \\
\text { meler }\end{array}$ & Bitişik yazılmış & Bitişik yazılmış & \\
\hline Özel isimler & Çeviri yazı & Çeviri yazı & Yazım Kılavuzu \\
\hline Tamlamalar & Belirtilmiş & Belirtilmiş & Belirtilmiş \\
\hline Noktalama & Yapılmış & Yapılmış & Yapılmış \\
\hline Vâv-1 ma'dule & Gösterilmiş & Gösterilmiş & Gösterilmemiş \\
\hline
\end{tabular}

* Türkçe sözlükte bulunmayan ayın harfi ('), hemze ise (') işareti ile gösterilmiştir. Örnek: "etbâ', şenî‘, me' kul, re's."

** Farsça okunuşlar dikkate alınmıştır. "Kalem” değil, "kelem”; "gam” değil, "gem”. Sözlük sonunda Arap alfabesine göre dizilim verilmiştir.

Yukarıda adı geçen sözlükler Osmanlı Türkçesi ile hazırlanmış eserlerdir. $\mathrm{Bu}$ eserlerden ilk ikisinin bugünkü alfabe ile yazılmasında kullanılan sistem


Her sözlük kendi içinde uyumlu ve anlaşlır bir esasa göre yeni alfabeye aktarılmışsa da çeviri yazı ve yazım konusunda birbirinden farklılık gösterir. Bu sözlüklerde uygulanan çeviri yazı ve yazım kuralları örnekleriyle beraber aşağıda görülmektedir. 


\section{a. Uzatma Harfleri / حروف مد}

Uzatma harflerinden olan "ى،g،" (elif, vâv ve yâ) harfleri, Lügat-i Halîmìde

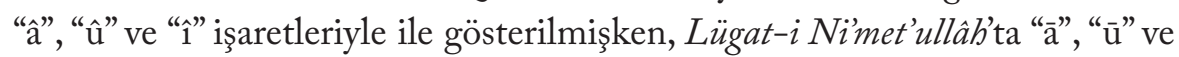
“i” şeklinde yazılmıştır. Örnekler:

\begin{tabular}{|c|c|c|c|c|}
\hline \multirow{4}{*}{ Lügat-i Halîmî } & ات ات & ...et & علامت خطابدر & 'Alâmet-i hitṭâbdur \\
\hline &  & encâm & اشك آخر & İşüy âhiri \\
\hline & | دور & dûr & ارق بعيد معناسنه & Iraḳ, $b a$ î̀ ma'nâsına \\
\hline & | ياسمن & yâsemen & بر معروف جֶجى در & Bir ma'rûf çiçekdür \\
\hline \multirow{4}{*}{ Lügat-i Ni'met'ullâh } & ات ات & et & ادات خطابدر & Edāt-1 hitābdur \\
\hline & 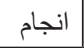 & encām & آخر كار & Āhir-i kār \\
\hline & مور & dūr & ارق بعيد معناسنه & Iraḳ, ba‘id ma‘nâsına \\
\hline & | باسمن & yāsemen & معروف آقجه جֶجִكدر & Ma'rūf akçca çiçekdür \\
\hline
\end{tabular}

Yukarıda görüldüğü üzere aynı sesi veren hecelerin farklı çeviri yazı ile yazıldığı görülmektedir. Bu kelimelerin Türk Dil Kurumu tarafindan hazırlattırı-


ise şöyledir:

\begin{tabular}{|c|c|c|c|c|}
\hline \multirow{4}{*}{$\begin{array}{l}\text { Burhân-l } \\
\qquad \text { Katı }\end{array}$} & ات & ...et & ضمير متصل خطابدر تو معناسنه & $\begin{array}{l}\text { Zamir-i muttasıl-1 hitâbdur } \\
\text { "tû" manasına }\end{array}$ \\
\hline &  & encâm & اندام وزننده صوكث و انتهاو آخر & $\begin{array}{l}\text { Endâm vezninde. Son, intiha } \\
\text { ve ahir manasınadır. }\end{array}$ \\
\hline & دور & dûr & مور وزننده اير اق و بعيد معناسنه در & $\begin{array}{l}\text { Mûr vezninde. Irak ve ba'id } \\
\text { manasınadır. }\end{array}$ \\
\hline & 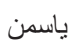 & yasemen & بو اسمله معروف جֶٍ & $\mathrm{Bu}$ isimle maruf çiçektir \\
\hline
\end{tabular}

Örneklerde görüldüğü üzere üç sözlükte de Arapça ve Farsça kökenli kelimeler farklı yazım ile yazılmıştır. Türkçe Sözlük'te "hitap” olarak yazılan ve aynı anlamda kullanılan kelime, Lügat-i Halîmîde "hiț̂â", Lügat-i Nimet'ullâb'da "hitậb" ve Burbân-ı Katı'da "hitâb” şeklinde yazılmıştır. Aynı şekilde son anlamina gelen "ahir" kelimesi de Lügat-i Halimîde "âhir”, Lügat-i Nimet’ullâb’ta


ki gibi "ahir" şeklinde yazılmıştır. "Maruf, mana ve baid" kelimeleri de her sözlükte farklı yazılmıştır. 


\section{b. Özel isimler ve yer adları}

Yabancı dillerden geçmiş ve genel olarak Türkçede kullanılan özel isimler ve yer adları da farklı yazılmıştır. Bu isimlerden Türkçede kullanılanlar da çeviri yazı ile kaydedilmiştir. Lügat-i Halîmîde "Sa'dî, Ḥ̂ffı̣, Kemâl, İșfahân, Hindistân”; Lügat-i Nimet’ullâb’ta "Peyg̉am-ber Hâfiẓ, Mevlānā Celālü'ddīn, Kirmān, Hindistān Çīn, 'Arabistān” şekline yazılmıştır. Burban-ı Katı'da ise çeviri yazı uygulanmamıştır. Aşağıdaki tabloda örnekler gösterilmiştir.

\begin{tabular}{|c|c|c|}
\hline $\begin{array}{l}\text { Lügat-i } \\
\text { Halîm }\end{array}$ & بِيغمبر، لطف هندان، كمال، سعدى، مولانا جلال & $\begin{array}{l}\text { Peyġamber, Lutfullah/Luțullah, } \\
\text { Șa‘dî, Mevlânâ Celâleddîn, Hindistân, } \\
\text { Kemâl }\end{array}$ \\
\hline $\begin{array}{l}\text { Lügat-i } \\
\text { Ni'met'ullâh }\end{array}$ & 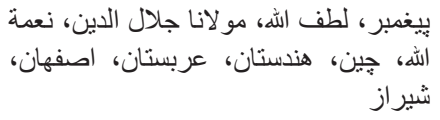 & $\begin{array}{l}\text { Peyġam-ber, Luțu'llāh, Mevlānā } \\
\text { Celālü'd-dīn, Ni‘metu'llāh, CCīn, } \\
\text { Hindistān, 'Arabistān, Ișfahān, Şīiāz }\end{array}$ \\
\hline Burhân-ı Katı & 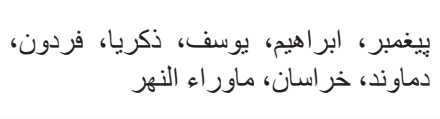 & $\begin{array}{l}\text { Peygamber, İbrahim, Yusuf, Zekeriya, } \\
\text { Feridun, Demavend, Horasan, } \\
\text { Maveraünnehir }\end{array}$ \\
\hline
\end{tabular}

Lügat-i Halîmî ve Lügat-i Nimet'ullâb'ta kitap isimlerinde de çeviri yazı alfabesi kullanılmıştır. Kitap adı büyük harfle başlayıp küçük harfle devam etmiştir. Eğer kitap adı bir tamlamadan ibaretse yine ilk kelime büyük harfle başlamış ve küçük harfle devam etmiştir. Sadece kitap adı içindeki özel isim, yer ve nispet bildiren kelimelerin ilk harfi büyük yazılmıştır. Örnek: Muntahab, Bahru'l-garâyib, Mi yâr-i Cemâlì; Fetāvā, Heft-peyker, Dakāylku'lhakāyılk, Mi yār-ı Cemâlî.

Burhân-ı Katı'da ise "Müeyyidü'l-Fuzelâ, Muhtasar-1 Vikâye, Ferheng-i Surûrî ve Ferheng-i Cihângîr̂̂” şeklinde her kelimenin ilk harfi büyük yazılmiştır.

\section{c. Tamlamalar}

Türkçenin Arapça ve Farsçadan etkilenmesiyle birlikte cümle içinde bu iki dildeki tamlamalar Türkçede görülmeye başlamıştır. Bu tamlamalar kendi dil kurallarına göre yapılarak Türkçe içerisinde kullanılan Arapça ve Farsça tamlamalarda yazım konusunda bir bütünlük görülmüştür. Ayrıca Arapçadan dilimize geçen tamlamalarda dilin kendi fonetiğinde bulunan şemsi ve kameri harfler de okunuşta gösterilmiştir. Örnekler aşağıdaki tabloda verilmiştir. 


\begin{tabular}{|c|c|c|c|}
\hline & Lügat-i Halîmî & Lügat-i Ni'met'ullâh & Burhân-ı Katı \\
\hline Arapça Tamlamalar & $\begin{array}{l}\text { Baḥru'l-garâyib } \\
\text { Beytu'l-Mukaddes } \\
\text { Mâverâu'n-nehr } \\
\text { ale't-ta'cîl } \\
\text { fi'l-cümle }\end{array}$ & $\begin{array}{l}\text { Baḥrü'l-gaarāyib } \\
\text { Beytü'l-'ankebūt } \\
\text { ḥabbü'l-gāar } \\
\text { rubbü'l-'ineb, mā'u'l-ḥadidd }\end{array}$ & $\begin{array}{l}\text { bi'l-ehli ve'l-iyâl } \\
\text { ebu'l-melîh } \\
\text { aynü'l-bakar } \\
\text { tînu'l-ahmak } \\
\text { bade't-tenavül } \\
\text { Maveraünnehr }\end{array}$ \\
\hline Farsça Tamlamalar & $\begin{array}{l}\text { Mi‘yâr-i Cemâlî } \\
\text { ber sebîl-i gaalaṭ } \\
\text { vașf-1 terkîbî } \\
\text { ism-i mașdar } \\
\text { Târîh-i Fürs-i ḳadîm }\end{array}$ & $\begin{array}{l}\text { Mi'yār-i Cemālì } \\
\text { șig̀a-i emr } \\
\text { kesr-i şīn } \\
\text { āb-1 keșīi } \\
\text { rūy-i zemīn }\end{array}$ & $\begin{array}{l}\text { sükûn-i nûn } \\
\text { levn-i fistık } \\
\text { bâde-i sâf } \\
\text { âb-1 hayat } \\
\text { leb-i mahbûb } \\
\text { umur-i dünyeviye }\end{array}$ \\
\hline
\end{tabular}

Yukarıdaki örneklerde de görüldüğü üzere Türkçede kullanılan Arapça ve Farsça tamlamalarda çeviri yazı imlası/simgesi tercihi hariç bir değişiklik görülmemektedir. Burhân-ı Katı'da "Maveraünnehr" kelimesinde ise tamlama kuralı uygulanmamıştır.

Nispet bildiren kelimelerde, çeviri yazı alfabesinde tercih edilen simgeden kaynaklanan bir yazım farklılı̆̆ı ortaya çıkmakla birlikte, fonetiğinde değişiklik yoktur. Örnek: "Rûmî, Rūmī, Rumî; Şîrâzî, Şïrāzī, Şirazî; Türkî, Türkī, Türkî, 'Arabî, ‘Arabī, Arabî; Fârisî, Fārisīi, Fârisî.”

Lügat-i Halîmî ile Lügat-i Nimet'ullẩ'ta hem Arapça ve Farsça kökenli kelimelerde hem de Türkçe kelimelerde çeviri yazı alfabesi kullanılmı̧̧ır. Burbân-ı Katı'da ise çeviri yazı alfabesi kullanılmamış, bazı kelimelerde uzatma işaretleri ile Arapça ve Farsça tamlamalar belirtilmiştir. Örnek: "Aynü’1bakar, haceru'n-nur, sâhib-i servet, nefes-i şedid."

\section{d. Madde başları}

Osmanlı Türkçesi ile yazılan Farsça-Türkçe sözlüklerin çeviri yazı ile bugünkü alfabeye aktarılması esnasında madde başları da farklı oluşturulmuştur. 
$\sqrt{ }$ Lügat-i Halîmîde madde başları Arap alfabesine göre alfabetik olarak dizilmiştir. Madde başları koyu, okunuşları eğik ve (:) iki noktadan sonra açıklama kısmına geçilmiştir.

$\sqrt{ }$ Lügat-i Nimet'ullâb'ta madde başları yine Arap alfabesine göre alfabetik olarak dizilmiştir. Madde başları koyu, okunuşları da koyu olarak verilmiş ve herhangi bir noktama işareti konmadan açıklamaya geçilmiştir.

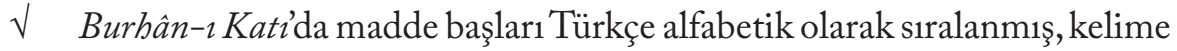
Arap alfabesiyle parantez içerisinde yazılmıştır. Daha sonra herhangi bir noktalama işareti konmadan açıklamaya geçilmiştir.

Yukarıda sözlüklerden verilen örnekler, tablo hâlinde aşağıdadır.

\begin{tabular}{|c|c|c|c|}
\hline & Lügat-i Halîmî & Lügat-i Ni'met'ullâh & Burhân-ı Katı \\
\hline $\begin{array}{l}\text { Türkçe } \\
\text { kelimeler }\end{array}$ & $\begin{array}{l}\text { soyra, șu, yaġmak, } \\
\text { ḳorhu, țaru, dèr }\end{array}$ & $\begin{array}{l}\text { anuy, șalkıım, țaş, } \\
\text { buğday, dérler, ag̉aç }\end{array}$ & $\begin{array}{l}\text { gece, konak, gizli, su, } \\
\text { yağmur, kapı, ağaç }\end{array}$ \\
\hline $\begin{array}{l}\text { Arapça } \\
\text { kelimeler }\end{array}$ & $\begin{array}{l}\text { ma rûf, dakîị, sâabit } \\
\text { bahîil, taḥrîf, şâ'ir }\end{array}$ & $\begin{array}{l}\text { telaffuz, gazżab, te'hīir, } \\
\text { rivāyet, ma 'lūm, sâhạib }\end{array}$ & $\begin{array}{l}\text { takdim, mana, nevi, } \\
\text { tevazu, İslâm, tabir }\end{array}$ \\
\hline $\begin{array}{l}\text { Farsça } \\
\text { Kelimeler }\end{array}$ & $\begin{array}{l}\text { behâr, merd, hâr, cân, } \\
\text { cevân, murdâr }\end{array}$ & $\begin{array}{l}\text { Pāre, merd, dūst, (dost), } \\
\text { revān, cān }\end{array}$ & $\begin{array}{l}\text { dergâh, âsitâne, şagirt, } \\
\text { civan, bûse }\end{array}$ \\
\hline $\begin{array}{l}\text { Arapça } \\
\text { Tamlamalar }\end{array}$ & $\begin{array}{l}\text { Beytu'l-Muḳaddes, } \\
\text { şeceretü'l-bek, } \\
\text { rubbu'l- 'ineb, dâru'ş- } \\
\text { şifâ }\end{array}$ & $\begin{array}{l}\text { ḥabbü'l-gāār, } \\
\text { rubbü'l-'ineb, } \\
\text { mā'u'l-ḥadid, } \\
\text { ețibbā'ü'l-kelb }\end{array}$ & $\begin{array}{l}\text { devâu'1-hayye, } \\
\text { zîku'n-nefs, } \\
\text { bade't-tenavül }\end{array}$ \\
\hline $\begin{array}{l}\text { Farsça } \\
\text { Tamlamalar }\end{array}$ & $\begin{array}{l}\text { Târîhn-i Fürs-i ḳadîm, } \\
\text { vașf-1 terkîbî, } \\
\text { ism-i mașdar, } \\
\text { edât-1 nisbet }\end{array}$ & $\begin{array}{l}\text { rūḥ-1 ḥayvānī, dīnār-1 } \\
\text { revān, rūy-i zemīn, } \\
\text { kemer-i zerrīn, } \\
\text { kelime-i taḥsīn }\end{array}$ & $\begin{array}{l}\text { selâtin-i İran, def-i su-i } \\
\text { nazar, kelime-i taaccüb, } \\
\text { müddet-i kalil, zir-i } \\
\text { zemin }\end{array}$ \\
\hline Özel İsimler & $\begin{array}{l}\text { İbrâhîm, Kemâl, } \\
\text { Nizâmî, Lațîfî, Ḥâfız, } \\
\text { Esedî, Ferîdûn, } \\
\text { Ebû'l-Mü'eyyed, } \\
\text { Mâverâ'u'n-nehr, } \\
\text { İșfahân, Hindustân }\end{array}$ & $\begin{array}{l}\text { Halīmī, Nerīmān, Sulțān } \\
\text { Maḥmūd, Rüstem-i Zāl, } \\
\text { Lațîî, Żarīif-i Reyyānī, } \\
\text { Hindūstān, Anațolı, } \\
\text { Māverā'ü’n-nehr }\end{array}$ & $\begin{array}{l}\text { Hamza, Ebu Cehil, } \\
\text { Ferid, Deccâl, Zahhâk-i } \\
\text { Marî, Hazret-i Nuh, } \\
\text { Bedahşan, Talekan, } \\
\text { Estarâbâd, Çin }\end{array}$ \\
\hline Kitap İsimleri & $\begin{array}{l}\text { Lüccetü'l- 'Acem, } \\
\text { Baḥru'l-garâyib, } \\
\text { Mi yâr-i Cemâlî, } \\
\text { Șị̣âḥ̣u'l-Fürs }\end{array}$ & 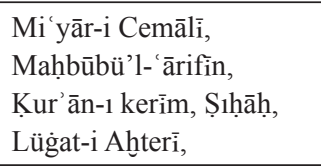 & $\begin{array}{l}\text { Mecma 'u'l-Furs, } \\
\text { Kur'an-1 Azimü'ş-şân, }\end{array}$ \\
\hline Madde Başları & $\begin{array}{l}\text { سرد serd: Șovuk, berd } \\
\text { ma'nâsina. }\end{array}$ & $\begin{array}{l}\text { سرد serd Șovuk, 'Arabca } \\
\text { berd ma nāsina. }\end{array}$ & $\begin{array}{l}\text { Fereștûk (فرشتوك) } \\
\text { Kırlangıç kuşudur. } \\
\text { Arabîde huttâf (خطاف) } \\
\text { denir. }\end{array}$ \\
\hline
\end{tabular}


Örneklerde görüldüğü üzere sözlüklerde çeviri yazı yönteminde takip edilen usulde yazım farklılığı mevcuttur. Yukarıda belirtildiği üzere bu sözlüklerde farklı yazımların bulunması, yapılan çalışmanın akademik olmadığını göstermiyor. Aksine bu çalışmaların kendi içinde genel bir bütünlüğü de olabilir. Ancak basımı yapılan yayınlarda aynı anlamı veren kelimelerin farklı yazılması okuyucu açısından bir karışıklığa sebep olabileceği gibi anlam farklilığına da yol açacaktır. Sonuçta hem resmî yazışmalarda hem de bilimsel çalışmalarda bir bütünlük sağlanmamış olacaktır.

Eski metinlerin yeni alfabeye aktarılması konusunda araştırmacılar tarafından farklı görüşler öne sürülmüştür. Bu konuda 1946'da Millî Eğitim Bakanlığ1 tarafindan yayımlanan Türk İlmî Transkripsiyon Kılavuzu adlı eserde şu ifade dikkat çekicidir:

"Eski türk alfabeleri ile yazılmış olup, bugünkü yazımıza çevrilmesi zarûrî olan eserlerin bir kısmı, belki de en büyük kısmı, mektepler, kütüphâneler ve geniş okuyucu kitlesini te’min etmek üzere, gündelik hayatta kullanılmasına lüzum görülen eserler olacaktır. Bu nevi metinler, neşredenler tarafindan iyice araştırılmış ve dil bilgisinin en son izah imkânlarından istifade edilerek, okunmuş, işlenmiş ve normalleştirilmiş olacaklarn gibi, bunlardan istifâde edenler de, Türk kültürüne âit bu gibi metinlerin tesbit șekli mes'eleleri ile alâkadar olmayacaklardır. Asıl metinlerin içindekiler mübim olacağı için, neşredildikleri zaman, bunların bütün imlâ bususiyetlerine işâret edilmeyerek, yalniz en zârurî noktaların belirtilmesi ile iktifa edilecektir.

Eserlerin bir kısmı da, doğrudan doğruya metin olarak neşredilmesi zarûri olan ve Türk kültürünün gelişme taribi bakımındaan çok mühim ve her cibetten tetkiki lüzumlu bulunanlardır. Bu gibi eserleri de, mümkün mertebe fotoğraf yolu ile, faksimile hâlinde neşretmeye çalıșmakla beraber, bunların ya metinlerdeki bütün husûsiyetleri gözetilerek, dar mânada, yâni geniş̧ ölçüde normalleştirilmiş tam bir transkripsiyonunun yapılması yahut, bütün teferruatı ayrıca gösterilmek şartı ile, geniş mânada, yâni dar ölçüde normalleştirilmesi zarûrîdir (1946: 3-4)".

Yukarıda ifade edildiği üzere metin neşirlerinde iki tür çalışma ortaya çıkmaktadır. Eski Türk alfabesi ile yazılmış ve bugünkü alfabeye aktarılması önemli olan bu tür eserlerin; 
1. Metnin bugünkü alfabe ile yazılması (İçeriğin önemi ve okuyucu odaklı)

2. Tıpkıbasım yapılması ve çeviri yazı alfabesi ile yazılması (Eserin önemi)

şeklinde iki başlıkta değerlendirilmesi mümkündür. İçeriğin önemli olduğu ve okuyucunun istifadesine sunulması gerekli olduğu eski Türk alfabesi ile yazılan eserler içerisinde Osmanlı Türkçesi ile yazılan Türkçe, Farsça-Türkçe, ArapçaTürkçe sözlükler sayılabilir. Bu itibarla okuyucu burada sözlük içindeki metin tespiti, şekli ve yazımını değil, kelime anlamlarını öğrenmeye çalışacaktır.

Yukarıda ifade edilen iki başlıktan hareketle birinci başlık için şunu söylemek mümkündür. Ĕğer bir akademik çalışma, kurum veya başka bir kuruluş tarafından yayımlanacaksa yazım birlikteliğinin sağlanması gerekir. Bu tür metinlerde ve yayınlarda Türkçe yazım kuralları dikkate alınmalıdır. Yabancı bir dilin kuralından hareketle kelimeler oluşturulmamalı ve yazılmamalıdır. Çünkü o kelimeler y1llarca söz hazinemizde bulunmuş ve bir anlam bütünlüğü içinde cümlelerde kullanılagelmiştir, bizimdir ve Türkçenin kurallarına göre yazılmalıdır.

İkinci başlıkta ise eserin önemine binaen birebir çalışmasını hazırlamak, gerekli oldukça daha sonraki çalışmalarda istifade etmek ve dildeki gelişmeleri takip etmek ve izlemek amacıyla çalı̧̧ma yapılması önerilmektedir. Kâşgarlı Mahmud'un Divanü Lügati't-Türk'ü buna bir örnektir. Bunun gibi eserlerde asıl ifadelere ve metinlere ihtiyaç vardır ve olduğu gibi yayımlanmalıdır.

Bilindiği üzere yazım kılavuzu hazırlama, Türk Dil Kurumunun görevleri arasında bulunmaktadır. Bu itibarla Kurum tarafindan Yazım Kılavuzu hazırlanmış ve tüm resmî dairelerde, kamu kurumlarında, sivil toplum örgütlerinde ve ülkemizde Türkçe ile yapılan yazışmaların tamamında bu kılavuz kullanılmaktadır. Fakat Türk Dil Kurumu tarafından yayımlanan Türkçe sözlükle diğer kurumlar ya da şahıslar tarafından yayımlanan sözlükler arasında yazım konusunda da bir birliktelik bulunmamaktadır.

\section{Türkçe Sözlükler}

Burada söz konusu olan Türkçe sözlükler ve onların türleri değil, yabancı dillerden özellikle de Doğu dillerinden dilimize geçmiş ve artık bizim söz hazinemizde bulunan kelimelerin sözlüklerde nasıl yazıldığıdır. Aşağıda Türk Dil Kurumu tarafindan yayımlanan Türkçe Sözlük (TS) (2011), Millî Eğitim Bakanlığ1 tarafından yayımlanan Örnekleriyle Türkşe Sözlük (ÖTS) (2000), Kubbealtı İktisadi İşletmesi tarafından yayımlanan Misalli Büyük Türkşe Sözlük (MBTS) (2011) ve D. Mehmet Doğan tarafından yayımlanan Büyük Türkşe Sözlük (BTS)'te (1996) madde başı olarak yazılan bazı Arapça kökenli kelimelerin yazılış, okunuş ve çeviri yazı örnekleri görülmektedir. 


\begin{tabular}{|l|c|c|c|c|}
\cline { 2 - 5 } \multicolumn{1}{c|}{} & $\begin{array}{c}\text { Türkçe } \\
\text { Sözlük }\end{array}$ & $\begin{array}{c}\text { Örnekleriyle } \\
\text { Türkçe Sözlük }\end{array}$ & $\begin{array}{c}\text { Misalli Büyük } \\
\text { Türkçe Sözlük }\end{array}$ & $\begin{array}{c}\text { Büyük Türkçe } \\
\text { Sözlük }\end{array}$ \\
\hline Yazılış & alicenap & âlîcenap & $\begin{array}{c}\text { ÂLÎCENAP- } \\
\text { ÂLÎCENAB }\end{array}$ & âlîcenap \\
\hline Okunuş & a:li:cenap & - & $($ ع) & $(--.-)$ \\
\hline Çeviri Yazı & 'ālì + cenāb & 'āli-cenāb & 'āli-cenâb & - \\
\hline Tür & sf. & s. & sif. ve i. & F.s. \\
\hline
\end{tabular}

\begin{tabular}{|l|c|c|c|c|}
\cline { 2 - 5 } \multicolumn{1}{c|}{} & $\begin{array}{c}\text { Türkçe } \\
\text { Sözlük }\end{array}$ & $\begin{array}{c}\text { Örnekleriyle } \\
\text { Türkçe Sözlük }\end{array}$ & $\begin{array}{c}\text { Misalli Büyük } \\
\text { Türkçe Sözlük }\end{array}$ & $\begin{array}{c}\text { Büyük Türkçe } \\
\text { Sözlük }\end{array}$ \\
\hline Yazılış & kablelmilat & kablelmilât & $\begin{array}{c}\text { KABL (Kable'l- } \\
\text { mîlâd) }\end{array}$ & kablelmilât \\
\hline Okunuş & ka'blelmi:lat & - & ( $)$ & - \\
\hline Çeviri Yazl & ḳabl + mīlād & ḳabl-el- mīlād & ḳabl & - \\
\hline Tür & zf. & i. & zf. & b.z. \\
\hline
\end{tabular}

\begin{tabular}{|c|c|c|c|c|}
\cline { 2 - 5 } \multicolumn{1}{c|}{} & $\begin{array}{c}\text { Türkçe } \\
\text { Sözlük }\end{array}$ & $\begin{array}{c}\text { Örnekleriyle } \\
\text { Türkçe Sözlük }\end{array}$ & $\begin{array}{c}\text { Misalli Büyük } \\
\text { Türkçe Sözlük }\end{array}$ & $\begin{array}{c}\text { Büyük Türkçe } \\
\text { Sözlük }\end{array}$ \\
\hline Yazılış & tecahülüarif & tecâhül-ü ârif & $\begin{array}{c}\text { TECÂHÜL } \\
\text { (Tecâhül-i ârif) }\end{array}$ & $\begin{array}{c}\text { tecâhül } \\
\text { (tecâhül-i } \\
\text { ârifâne) }\end{array}$ \\
\hline Okunuş & teca:hü'lüa:rif & - & (تجإ) & (.-.) \\
\hline Çeviri Yazı & tecâhul+' 'ārif & tecāhül & cehl tecâhhul & - \\
\hline Tür & a. & ed. & i. & i. \\
\hline
\end{tabular}




\begin{tabular}{|c|c|c|c|c|}
\hline & $\begin{array}{l}\text { Türkçe } \\
\text { Sözlük }\end{array}$ & $\begin{array}{l}\text { Örnekleriyle } \\
\text { Türkçe Sözlük }\end{array}$ & $\begin{array}{l}\text { Misalli Büyük } \\
\text { Türkçe Sözlük }\end{array}$ & $\begin{array}{l}\text { Büyük Türkçe } \\
\text { Sözlük }\end{array}$ \\
\hline Yazılış & velinimet & velînîmet & VELÎNÎMET & velinimet \\
\hline Okunuş & veli:ni:met & - & (ولى نعمت) & $(.--)$. \\
\hline Çeviri Yazı & velï + ni'met & veliyy-i ni 'met & velī-ni'met & - \\
\hline Tür & a. & b.i. & i. & b.i. \\
\hline
\end{tabular}

Örneklerde görüldüğü üzere, çeviri yazı aktarımında bir esas olmakla birlikte Türkçe yazımında farklılıklar mevcuttur. Madde başı kelimelerin büyük/küçük yazımı da birbirinden farklıdır. Örneğin çoğu sözlükte madde başı, özel isimler hariç, hep küçük harfle yazılmıştır. Fakat Misalli Büyük Türkçe Sözlük (MBTS)'te tamamı büyük yazılmıştır. Bu sözlükte ayrıca madde, kendi asıl alfabesiyle de gösterilmiştir. Kelime türü açıklanırken yapılan kısaltmalarda da diğer sözlüklerle bir bütünlük bulunmamaktadır.

Arapça ve Farsça kökenli Türkçe birleşik kelimelerde de aynı durum mevcuttur. Aşağıdaki örneklerde Türk Dil Kurumu Türkşe Sözlüktteki “esrarengiz, fevkalbeşer, haramzade, hayırperver, izaleişüyu, kadirşinas, tebdilihava ve zevküsefa" kelimeleri Örnekleriyle Türkşe Sözlük'te "fevkalbeşer, hayırperver ve kadirşinas" kelimeleri aynı yazım ile yazılırken "esrârengiz, haramzâde, izâleişüyû, tebdîlihava ve zevk u safâ" kelimeleri ise bazı hecelerdeki uzatma durumunu gösteren ( $\left.{ }^{(}\right)$işareti ile yazılmıştır. Örnekleriye Türkçe Sözlük'te de Türk Dil Kurumu sözlügüne göre sadece "fevkalbeşer" ve "hayırsever" kelimeleri aynı yazım ile, diğerleri (esrârengiz, haramzâde, izâle-i şüyû, kadirşinâs, tebdîl-i hava, zevk u safa) ise farklı yazılmıştır. Büyük Türkşe Sözlük'te ise iki kelime farklı, diğerleri aynı yazım ile yazılmışıı. Aşağıdaki tabloda örnekler görülmektedir.

\begin{tabular}{|c|l|l|l|l|l|l|l|l|}
\hline TS & esrarengiz & fevkalbeşer & haramzade & hayırperver & izaleişüyu & kadirşinas & tebdilihava & zevküsefa \\
\hline ÖTS & esrârengiz & fevkalbeşer & haramzâde & hayırperver & izâleişüyû & kadirşinas & tebdîlihava & zevk u safâ \\
\hline MBTS & esrârengiz & fevkalbeşer & haramzâde & hayırsever & izâle-i şüyû & kadirşinâs & tebdîl-i hava & zevk u safa \\
\hline BTS & esrarengiz & fevkalbeşer & haramzâde & hayırperver & izale-i şüyu & kadirşinas & tebdilihava & - \\
\hline
\end{tabular}

Yine bu sözlüklerde yukarıda yazılan birleşik kelimelerin dışında da farklı imlaların bulunduğu kelimelerle karşılaşmak mümkündür. Bunlardan bazı örnekler, aşağıdaki tabloda görülmektedir. 


\begin{tabular}{|c|c|l|l|l|l|l|l|l|l|l|}
\hline TS & amade & kafiye & kiyamet & piyade & şümullü & tebarüz & azimkâr & mağrurane & talimgâh & yazihane \\
\hline ÖTS & âmâde & kafiye & kıyâmet & piyâde & şümûllü & tebârüz & azîmkâr & mağrûrâne & tâlimgâh & yazihâne \\
\hline MBTS & âmâde & kâfiye & kiyâmet & piyâde & şümullü & tebârüz & azimkâr & mağrûrâne & tâlimgâh & yazihâne \\
\hline BTS & âmade & kafiye & kiyamet & piyade & şümûllü & tebârüz & azimkâr & mağrurane & tâlimgâh & yazihane \\
\hline
\end{tabular}

Ayrıca bu sözlüklerde, doğu kökenli kelime olup söz varlı̆̆ımızın bir parçası olan ve aynı yazım ile yazılan kelimeler olduğu gibi çok az yazım değişikliği olan kelimeler de mevcuttur.

\begin{tabular}{|c|c|c|c|c|c|c|c|c|c|c|c|c|c|c|}
\hline TS & adam & aksi & beygir & ceza & cüda & çapraz & çeçeve & derman & eşya & hâl & perhiz & saat & sabah & tesir \\
\hline ÖTS & adam & aksi & beygir & cezâ & cüdâ & çapraz & çeçeve & dermân & eşyâ & hâl & perhiz & saat & sabâh & tesîr \\
\hline MBTS & adam & aksi & beygir & cezâa & cüdâ & çapraz & çeçeve & derman & eşyâa & hâl & perhiz & saat & sabah & tesir \\
\hline BTS & adam & aksi & beygir & ceza & cüdâ & çapraz & çerçeve & derman & eşya & hâl & perhiz & saat & sabah & tesir \\
\hline
\end{tabular}

Osmanlıca-Türkçe olarak hazırlanan sözlüklerde özellikle de Ferit Develioğlu'nun hazırladığı Osmanlıca-Türkşe Ansiklopedik Lîgat ile Türkiye Kalkınma ve Dayanı̧̧ma Vakfı (TÜRDAV) tarafından yayımlanan Osmanlıca Türkşe Ansiklopedik Büyük Lûgat’te daha farklı bir yazım esası takip edilmiştir. Ferit Develioğlu kendi ifadesiyle "İmla Kılavuzu kurallarına bağglı kalınmadığını” söylemiş, fakat hazırladığı sözlüğün yazım usullerini eserin giriş kısmında açılamıştır. Bu usulde ise madde başlarındaki uzun seslilerin üzerine ( ( ) işareti konulmuştur. Kelimeler köken itibarıla asıl alfabeyle de yazıldığı için çeviri yazı alfabesi kullanılmamıştır. TÜRDAV'ın yayımlad1ğ1 sözlükte de kelimeler kendi asli alfabesiyle yazılmıştır. Fakat kelimelerin Latin alfabesiyle yazımında daha çok bugünkü okunuş dikkate alınmıştır. Bu itibarla TÜRDAV'ın sözlüğünde bugünkü Türkçe yazım öne çıkmıştır. Ferit Develioğlu'nun sözlüğünde kelimenin asıl alfabe ile yazımı maddeden sonra iken, TÜRDAV'da ise maddeden önce yazılmıştır. Aşağıdaki tabloda bu sözlüklerin, asıl alfabeyle birlikte bazı madde başlarının Türkçe yazımları görülmektedir.

\begin{tabular}{|c|c|c|c|c|c|c|c|}
\hline F. Develioğlu & âdem & aksî & bâr-gîr & cezâ' & cüdâ & çep ü râst & çâr-çûbe \\
\hline Arap Alfabe & آدم & عكسى & باركير & جزاء & جدا & رَّ" & جار جوبه \\
\hline TÜRDAV & adam & aksi & bargir & ceza & cüda & çep ü rast & - \\
\hline F. Develioğlu & dermân & eşyâ' & hâl & perhiz & sâat & sabâh & te'sir \\
\hline Arap Alfabe & درمان & اشياء & حال ل & بر هيز & ساعت & صباح & ت تأثير \\
\hline TÜRDAV & derman & eşya & hal & perhiz & saat & sabah & te'sir \\
\hline
\end{tabular}


Yukarıda örneklerin verildiği sözlüklerde dilimize girmiş doğu kökenli kelimelerde yazım farklarının olduğu görülmektedir. Bu farklar her ne kadar kelimeden kelimeye değişse de her sözlüğün giriş kısmında sözlük içinde kullanılan yazım kurallarının kelimelere nasıl yansıdığının anlatıldığı bölüm vardır. Yazar sözlüğünü bu esasa göre hazırlamıştır. Bu açıdan bakıldığında araştırmacı kendi içinde bir sistem dâhilinde sözlüğü hazırlamış olabilir. Fakat bütün bunlarla birlikte sözlüklerde aynı anlamda kullanılan kelimelerin farklı yazım ile yazıldığı da ortadadır.

Farsça-Türkçe sözlüklerdeki örneklerde de farklı yazım kullanılmıştır. Arapça ve Farsçadan dilimize geçmiş ve hâlen kullanmakta olduğumuz bazı kelimelerin sözlüklerdeki yazılışları aşağıdaki tabloda verilmiştir.

\section{Arapça Kelimeler}

\begin{tabular}{|c|c|c|c|c|c|c|}
\hline Lügat-i Halîmî & isti mâl & mahṣûș & nâfi‘ & țabîb & fi'l-hâl & ism-i fầil \\
\hline Lügat-i Ni'met'ullâh & isti'māl & mahṣūṣ & nāfi‘ & țabib & fi'l-hāl & ism-i fā'il \\
\hline Burhân-ı Katı & istimal & mahsus & nafi & tabip & fi'l-hâl & ism-i fầil \\
\hline $\begin{array}{l}\text { Osmanlıca-Türkçe } \\
\text { Ansiklopedik Lûgat }\end{array}$ & isti'mâl & mahsûs & nâfi' & tabîb & fi-l-hâl & ism-i fâil \\
\hline $\begin{array}{l}\text { Osmanlıca Türkçe } \\
\text { Ansiklopedik Büyük } \\
\text { Lîgat }\end{array}$ & isti'mal & mahsus & nafi' & tabib & filhal & ism-i fâil \\
\hline Türkçe Sözlük & istimal & mahsus & nafi & tabip & - & - \\
\hline $\begin{array}{l}\text { Örnekleriyle Türkçe } \\
\text { Sözlükk }\end{array}$ & istîmâl & mahsûs & nâfi & tabîb/tabip & filhâl & - \\
\hline $\begin{array}{l}\text { Misalli Büyük } \\
\text { Türkçe Sözlük }\end{array}$ & istîmal & mahsus & nâfi & tabib, tabip & filhal & ism-i fâil \\
\hline Büyük Türkçe Sözlük & istimal & mahsus & nâfi & tabip & filhâl & $-*$ \\
\hline
\end{tabular}

* D. Mehmet Doğan, isimle birlikte kullanılan kelimeleri tamlama şeklinde yazmaktadır. Örnek: "ism-i âzam, ism-i celâl" gibi. 
Farsça Kelimeler

\begin{tabular}{|c|c|c|c|c|c|c|}
\hline Lügat-i Halîmî & âsâyiş & âyîne & dîvâr & dil-âver & ser-âb & dest-gâh \\
\hline $\begin{array}{l}\text { Lügat-i } \\
\text { Ni'met'ullâh }\end{array}$ & āsāyiş & āyīne & dīvār & dil-āver & ser-āb & dest-gāh \\
\hline Burhân-ı Katı & asayiş & ayna & duvar & dilaver & serap & tezgah \\
\hline $\begin{array}{l}\text { Osmanlıca-Türkçe } \\
\text { Ansiklopedik } \\
\text { Lîgat }\end{array}$ & âsâyiş & âyîne/ayna & $\begin{array}{l}\text { dîvâr, } \\
\text { duvar }\end{array}$ & dil-âver & $\begin{array}{l}\text { serâb, } \\
\text { serâp }\end{array}$ & $\begin{array}{l}\text { dest-gâh, } \\
\text { tezgâh }\end{array}$ \\
\hline $\begin{array}{l}\text { Osmanlıca Türkçe } \\
\text { Ansiklopedik } \\
\text { Büyük Lûgat }\end{array}$ & asayiş & ayine, ayna & $\begin{array}{l}\text { divar, } \\
\text { duvar }\end{array}$ & dil-aver & serab & $\begin{array}{l}\text { dest-gah, } \\
\text { tezgah }\end{array}$ \\
\hline Türkçe Sözlük & asayiş & ayna & duvar & dilaver & serap & tezgâh \\
\hline $\begin{array}{l}\text { Örnekleriyle } \\
\text { Türkçe Sözlük }\end{array}$ & âsâyiş & âyîne, ayna & $\begin{array}{l}\text { dîvâr, } \\
\text { duvar }\end{array}$ & dilâver & $\begin{array}{l}\text { serâb, } \\
\text { serap }\end{array}$ & tezgâh \\
\hline $\begin{array}{l}\text { Misalli Büyükk } \\
\text { Türkçe Sözlü̈k }\end{array}$ & âsâyiş & âyîne, ayna & $\begin{array}{l}\text { dîvar, } \\
\text { duvar }\end{array}$ & dilâver & serap & tezgâh \\
\hline $\begin{array}{l}\text { Büyük Türkçe } \\
\text { Sözlü̈k }\end{array}$ & âsâyiş & âyine, ayna & duvar & dilâver & $\begin{array}{l}\text { serab, } \\
\text { serap }\end{array}$ & tezgâh \\
\hline
\end{tabular}




\section{SONUÇ}

Sürekli gelişen ve değişen canlı bir varlık olarak bilinen dilin kendi alfabesinde var olan tüm seslerini başka bir alfabeye aktarma işi, bilim adamlarının üzerinde çalıştığı önemli alanlardan biridir. Bu alanda yapılan tartışmalar ve çözüm önerileri birçok sorunu ortadan kaldırmışsa da hâlâ çeviri yazı ve yazım konusunda sorunlar tam olarak çözülmüş sayılmaz.

Günümüzde çeviri yazı sistemi kullanılarak sözlük ve eski edebî metinler alanında birçok çalışma yapılmış ve yapılmaya da devam edilecektir. Çünkü sözlük ve edebi metinler milletin kültür hazinesini geleceğe taşıyan araçlardır. $\mathrm{Bu}$ açıdan çalışmalarda hedef kitleyi tereddüde düşürecek ve anlama zorluğu oluşturabilecek yazım farklılıklarından kaçınmak gerekir.

Ülkemizde Osmanlı Türkçesi ile yapılmış bilimsel çalışmalarda, günümüz Türkçesine aktarma işleminde uygulanan çeviri yazı alfabesi, iki temel esas

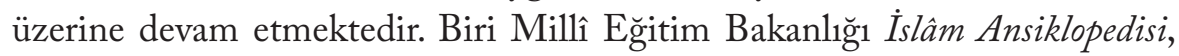
diğeri Türkiye Diyanet Vakfı İslâm Ansiklopedisidir. Bilimsel çalı̧̧malarda bütünlüğün sağlanması amaciyla bu iki temel esastan birinin tercih edilmesi veya yeni ilkelerin belirlenmesi yönünde çalı̧̧maların yapılması gereklidir.

Latin alfabesine geçişle birlikte ülkemizde sözlük çalışmaları hızlanmış, resmî kurumların yanı sıra özel girişimle de birçok Türkçe sözlük yayımlanmıştır. Bu sözlüklerde de, dilimizde kullanılan bazı Arapça ve Farsça kelimelerin yazımı konusunda birliktelik sağlanamamıştır. Bu nedenle Türkçe ve Osman11 Türkçesi ile hazırlanmış sözlüklere ilave olarak, Farsça Türkçe hazırlanan sözlüklerde de hem yazım hem de çeviri yazı yönünden farklılıkların giderilmesi için akademik çalışma grupları oluşturularak çözüme kavuşturulması önem arz etmektedir. 


\section{KAYNAKLAR}

Aksan, Doğan (2015). Her Yönüyle Dil, Ankara: Türk Dil Kurumu Yayınları. Ayverdi, İlhan (2011). Misalli Büyük Türkçe Sözlük, İstanbul: Kubbealtı İktisadi İşletmesi.

Banguoğlu, Tahsin (1995). Türķ̧enin Grameri, Ankara: Türk Dil Kurumu Yayınları.

Brockelmann, Carl (1909). Geschichte der Arabischen Litteratur, Leipzig: C.F. Amelangs Verlag.

Brockelmann, Carl vd. (1935). "Die Transliterasyon der arabischen Schrift in ihrer Anwendung auf die Hauptliteratursprahen der İslâmischen Welt", Leipzig: Denkschrift dem 19. İnternationalen Orietalistenkongre $\beta$ in Rom.

Doğan, D. Mehmet (2013). Büyük Türkşe Sözlük, Ankara: Yazar Yayınları.

Ergin, Muharrem (1995). Osmanlıca Dersleri, İstanbul: Boğaziçi Yayınları.

Hekim Bereket (2013). Tuhfe-i Mübârizî̀, haz. Binnur Erdağ 1 Doğuer. Ankara: Türk Dil Kurumu Yayınları.

Imlâ Lügati (1928). İstanbul: Devlet Matbaası.

Kavakçı, Yusuf Ziya (ths). İslâm Araştırmalarında Usul, Ankara: Diyanet İşleri Başkanlığ Yayınları.

Korkmaz, Zeynep (2009). Türkiye Türkşesi Grameri, Ankara: Türk Dil Kurumu Yayınları.

Lutfullah b. Ebî Yusuf (2013). Lügat-i Halîmî, haz. Adem Uzun. Ankara: Türk Dil Kurumu Yayınları.

Millî Eğitim Bakanlığı İslâm Ansiklopedisi (1941). I-, İstanbul: Millî Eğitim Basımevi.


Örs. İstanbul: Türk Dil Kurumu Yayınları.

Newby, Gordon D. (2004). A Concise Encylopedia of Islam, England: Oneworld Publications.

Ni'metu'llâh Ahmed (2015). Lügat-i Ni'metu'llâh, haz. Adnan İnce. Ankara: Türk Dil Kurumu Yayınları. 
Muallim Naci (2017). Istılâhât-ı Edebiyye, haz. M. A. Yekta Saraç. Ankara: Türk Dil Kurumu Yayınları.

Örnekleriyle Türkçe Sözlük (2000), İstanbul: Millî Eğitim Basımevi.

Şemseddin Sami (2015). Kamus-i Türkî, haz. Paşa Yavuzarslan. Ankara: Türk Dil Kurumu Yayınları.

Şeyhülislâm Mehmed Esad Efendi (199). Lehcetül-Lügat, haz. H. Ahmet Kırkkılıç. Ankara: Türk Dil Kurumu Yayınları.

Timurtaş, Faruk Kadri (1994). Yeni Türkiye Türķ̧esi, İstanbul: Enderun Kitabevi Yayınları.

Togan, A. Zeki Velidî (1981). Taribte Usûl, İstanbul: Enderun Kitabevi Yayinlar1.

Türkçe Sözlük (2011), Ankara: Türk Dil Kurumu Yayınları.

Türk İlmî Transkripsiyon Kılavuzu (1964), İstanbul: Millî Eğitim Basımevi.

Türkiye Diyanet Vakfi İslâm Ansiklopedisi (1988), I- ..., İstanbul: TDV Yayınlar1.

Yazım Kılavuzu (2012), Ankara: Türk Dil Kurumu Yayınları.

Yeni Tarama Sözlüğü (1983), dzl. Cem Dilçin. Ankara: Türk Dil Kurumu Yayınları.

\section{Makaleler}

Akçay, Yusuf (2007). "Osmanlı Dönemi Alfabe Tartı̧̧maları Bağlamında Dr. İsmail Hakkı Bey ve Islah-1 Huruf Cemiyeti”, Uluslararası Türk Dili ve Edebiyat Kongresi Nisan 2007 Erzurum.

Anhegger, Robert (Aralık 2017). "On transcribing Ottoman Text (Osmanlı Metinlerinin Transkripsiyonu üzerine)”. çev. H. Sercan Koşik. Karadeniz 18, s. $136-142$.

Durmuş, İsmail (2012). “Transkripsiyon”, Türkiye Diyanet Vakfi İslâm Ansiklopedisi 41, Ankara: TDV Yayınları.

Kaçalin, Mustafa S (1995). "Elifbâ”, Türkiye Diyanet Vakfi İslâm Ansiklopedisi 11, İstanbul: TDV Yayınları.

Pekacar, Çetin - Güner Dilek, Figen (2017). "Uluslararası Fonetik Alfabe-I”. Dil Araştırmaları 4, s. 135-150. 
Ulu, Cafer (2017), "Osmanlıda Alfabe Tartı̧̧maları ve Latin Alfabesinin Kabulü Sürecinde Mustafa Kemal'in Çıktığı Yurt Gezileri: Tekirdağ Örneği”” Ankara Üniversitesi Dergileri, s. 277-302. (Erişim tarihi: 10 Aralık 2017), http://dergiler.ankara.edu.tr/dergiler /18/1900/19970.pdf.

Ünver, İsmail (2008). “Çevriyazıda Yazım Birliği Üzerine Öneriler”, Turkish Studies 3/6, s. 1-45.

(2008), “Arap Harfli Türkçe Metinlerin Çevirisinde Karşılaşılan Yanlışlar”, Turkish Studies 3/6, s. 47-58. 